\title{
Studies on coccidian oocysts (Apicomplexa: Eucoccidiorida)
}

\author{
Estudos sobre oocistos de coccídios (Apicomplexa: Eucoccidiorida) \\ Bruno Pereira Berto ${ }^{1 *}$; Douglas McIntosh²; Carlos Wilson Gomes Lopes ${ }^{2}$
}

\begin{abstract}
${ }^{1}$ Departamento de Biologia Animal, Instituto de Biologia, Universidade Federal Rural do Rio de Janeiro - UFRRJ, Seropédica, RJ, Brasil ${ }^{2}$ Departamento de Parasitologia Animal, Instituto de Veterinária, Universidade Federal Rural do Rio de Janeiro - UFRRJ, Seropédica, RJ, Brasil
\end{abstract}

Received January 27, 2014

Accepted March 10, 2014

\begin{abstract}
The oocysts of the coccidia are robust structures, frequently isolated from the feces or urine of their hosts, which provide resistance to mechanical damage and allow the parasites to survive and remain infective for prolonged periods. The diagnosis of coccidiosis, species description and systematics, are all dependent upon characterization of the oocyst. Therefore, this review aimed to the provide a critical overview of the methodologies, advantages and limitations of the currently available morphological, morphometrical and molecular biology based approaches that may be utilized for characterization of these important structures. It has become apparent that no single methodology is sufficient to fully characterize these structures and the majority of researchers favor the use of combinational or polyphasic approaches.
\end{abstract}

Keywords: Morphology, morphometry, molecular studies, diagnostic tools, systematic, taxonomy.

\section{Resumo}

Os oocistos de coccídios são estruturas robustas, frequentemente isoladas das fezes ou urina de seus hospedeiros, os quais oferecem resistência a danos mecânicos e permitem que os parasitas sobrevivam e permaneçam infecciosos por períodos prolongados. O diagnóstico da coccidiose, descrição das espécies e sistemática são dependentes da caracterização do oocisto. Portanto, esta revisão teve como objetivo fornecer uma visão crítica das metodologias, vantagens e limitaçôes dos métodos morfológicos, morfométricos e moleculares que podem ser utilizados para a caracterizaçáo destas estruturas importantes. Tornou-se evidente que nenhuma metodologia única é suficiente para caracterizar completamente essas estruturas e que a maioria das pesquisas favorecem o uso de metodologias combinadas ou polifásicas.

Palavras-chave: Morfologia, morfometria, estudos moleculares, ferramentas de diagnóstico, sistemática, taxonomia.

\section{Introduction}

The coccidian oocyst is a resistant structure that protects the sporozoites, which are the infective forms of coccidiosis. The oocyst is usually exogenous being released within the feces of the host, and for that reason mophological characterization of the oocyst has been used for diagnosis, species description and in systematic studies since the primordium of parasitology. Currently, other experimental approaches including quantification of oocysts per gram of feces (OoPG), host specificity, aspects of the life cycle, sites of infection, pathogenicity, antigenicity and nucleotide sequencing data are available and serve to complement the traditional morphological characterization of the coccidia, providing enhancements to diagnosis and species identification (DUSZYNSKI; WILBER, 1997; TENTER et al., 2002; BERTO et al., 2011a).

The current review aimed to detail the process of characterization of coccidia using parameters associated with the oocysts. Thus,

\footnotetext{
${ }^{*}$ Corresponding author: Bruno Pereira Berto

Departamento de Biologia Animal, Instituto de Biologia, Universidade

Federal Rural do Rio de Janeiro - UFRRJ, BR-465, km 7, CEP 23897-970,

Seropédica, RJ, Brasil

e-mail: bertobp@ufrrj.br
}

an overview of methods and guidelines for morphological, morphometrical and molecular studies is presented herein. It is important to note, that this review did not seek to alter the guidelines produced by Duszynski and Wilber (1997), rather it sought to emphasize some recent advances in the use of morphological characteristics and to present a concise synopsis on the applications of morphometrical and molecular methods used for the characterization of sporulated coccidian oocysts.

\section{Taxonomic Review}

Coccidia belong to the Apicomplexa, Conoidasida, along with gregarinas by having complete, hollow, truncated conoid. The gregarines are allocated in Eugregarinorida, parasitizing invertebrates with the mature gamonts being extracellular. All coccidia are allocated in Eucoccidiorida, usually they infect vertebrates and have intracellular gamonts. The main plesiomorphy of the gregarines in relation to the primitive coccidia (Adeleorina) is syzygy, which corresponds to gametogony where gamonts develop 
closely, forming one or few microgametes (DUSZYNSKI et al., 1999; BARTA et al., 2012).

Cryptosporidium is a coccidium which has similar characteristics to gregarinas and to the higher coccidia. Barta et al. (2006) revealed the similarity between the feeding organelles and the epicytoplasmic localization of Cryptosporidium with gregarines, colpodellids and dinoflagellates; however, gametogony in Cryptosporidium does not occur by syzygy. These biological characteristics are supported by molecular phylogeny, with Cryptosporidium spp. having recently been shown to form a distinct clade between gregarinas and coccidia (BARTA et al., 2012).

Eucoccidiorida is subdivided into the families Adeleorina and Eimeriorina. Adeleorina comprises primitive coccidia which still develop syzygy. The main genera are Adelea, Adelina, Klossia and Legerella with monoxenous cycles in invertebrates; Klossiella in mammals, and the haemogregarines Dactylosoma, Babesiosoma, Haemogregarina, Desseria, Cyrilia, Hepatozoon, Hemolivia and Karyolosus with heteroxenous cycles (UPTON, 2000; BARTA et al., 2012). The oocysts of this group are polisporic and may be eliminated in the feces (e.g. Adelina dimidiata) or in urine (e.g. Klossiella spp.). Alternatively, they can be a trapped in the biomass of the host necessitating predation to liberate the sporozoites (e.g. Adelina palori, Hepatozoon spp.), or may inoculate sporozoites in the intermediate host (e.g. Haemogregarina spp.) (KOPEČNÁ et al., 2006; BERTO et al., 2010a; BARTA et al., 2012).

Eimeriorina comprises higher coccidia which develop gametogony where gamonts develop separately and the microgametocyte produces numerous microgametes. Prior to detailed studies on the biology of coccidia and the advent of molecular studies, the genera of Eimeriorina were separated according to the proportion of sporocysts and sporozoites per oocyst. Employing only those criteria, disporic tetrazoic oocysts were described as Isospora in various vertebrate and invertebrate hosts; a classification which disregarded some biological aspects that subsequently led to the establishment of the genus Cystoisospora and other tissue cyst-forming coccidia (Sarcocystidae). In the same way, tetrasporic dizoic oocysts were traditionally described as Eimeria, a practice which ignored biological characteristics which consequently led to the appointment of the genera Calyptospora, Choleoeimeria and Acroeimeria (LEVINE, 1985; SOULSBY, 1987; JIRKU et al., 2002; BARTA et al., 2012). The data presented in Table 1 differentiates the major validated genera of Eucoccidiorida according to the proportion of sporocysts and sporozoites per oocyst, groups, and additional aspects including sporocyst morphology, susceptible hosts, samples/ tissues for the recovery and identification of oocysts.

Recent phylogenetic systematic studies employing genotyping have served to confirm some of the assumptions of traditional taxonomy, but have also provided a basis for the resurrection of some taxa. As an example, the establishment of the Calyptosporiidae was supported by Calyptospora spp. which demonstrate distinct biology and morphology. Their life cycle is heteroxenous with sporozoites developing in basal cells of the intestinal mucosa of shrimps. The definitive hosts are fish, where tetrasporic dizoic oocysts develop in the liver. In addition, the sporocysts possess distinct characteristics such as suture, posterior extension and capitate/ acapitate sporopodia (FOURNIE et al., 2000; ALBUQUERQUE; BRASIL-SATO, 2010; WHIPPS et al., 2012).

Table 1. Proportion of sporocysts and sporozoites from oocysts of coccidia (Apicomplexa: Eucoccidiorida) recovered from samples.

\begin{tabular}{|c|c|c|c|c|c|c|}
\hline \multirow{21}{*}{ 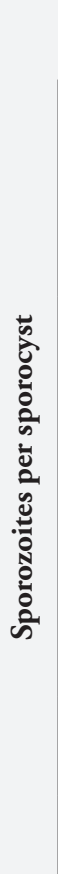 } & & \multicolumn{5}{|c|}{ Sporocysts per oocyst } \\
\hline & & $\mathbf{0}$ & 1 & 2 & 4 & Varied or many \\
\hline & 1 & & & & & Barroussia ${ }^{\mathrm{I}, \mathrm{b}}$ \\
\hline & 2 & & & Cyclospora ${ }^{\mathrm{IV}, \mathrm{VI}, 2, \mathrm{a}}$ & 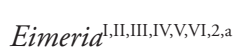 & Adelea $^{\mathrm{I}, 1, \mathrm{~b}}$ \\
\hline & & & & & Choleoeimeria ${ }^{\mathrm{IV}, \mathrm{b}, * *}$ & Adelina $^{\mathrm{I}, 1, \mathrm{~b}}$ \\
\hline & & & & & Acroeimeria $^{\mathrm{IV}, \mathrm{b}}$ & Pseudoklossia ${ }^{\mathrm{I}, \mathrm{b}, *}$ \\
\hline & & & & & Calyptospora ${ }^{\mathrm{II}, \mathrm{b}, * *}$ & Goussia $^{\mathrm{II}, \mathrm{III}, \mathrm{b}}$ \\
\hline & 4 & Cryptosporidium $^{\mathrm{V}, \mathrm{VI}}$ & & Isospora $^{\mathrm{III}, \mathrm{IV}, \mathrm{V}, 2, \mathrm{a}}$ & & Klossia $^{\mathrm{I}, \mathrm{l}, \mathrm{b}, *}$ \\
\hline & & & & Hyaloklossia ${ }^{\mathrm{III}, 3, \mathrm{~b}, *}$ & & \\
\hline & & & & Nephroisospora ${ }^{\mathrm{VI}, 3, \mathrm{~b}, *}$ & & \\
\hline & & & & Toxoplasma ${ }^{\mathrm{V}, \mathrm{V}, 3, \mathrm{~b}}$ & & \\
\hline & & & & Cystoisospora $^{\mathrm{V}, \mathrm{VI}, 3, \mathrm{~b}}$ & & \\
\hline & & & & Sarcocystis ${ }^{\mathrm{IV}, \mathrm{V}, \mathrm{V}, 3, \mathrm{~b}}$ & & \\
\hline & & & & Frenkelia ${ }^{\mathrm{V}, \mathrm{VI}, 3, \mathrm{~b}}$ & & \\
\hline & & & & Neospora ${ }^{\mathrm{VI}, 3, \mathrm{~b}}$ & & \\
\hline & & & & Hammondia ${ }^{\mathrm{VI}, 3, \mathrm{~b}}$ & & \\
\hline & & & & Besnoitia ${ }^{\mathrm{Vl}, 3, \mathrm{~b}}$ & & \\
\hline & 8 & Tyzzeria ${ }^{\mathrm{V}}$ & Caryospora $^{\mathrm{IV}, \mathrm{V}, \mathrm{a}, \mathrm{b}}$ & & & \\
\hline & & Pfeifferinella ${ }^{\mathrm{I}, * *}$ & & & & \\
\hline & Varied & & & & & Klossiella ${ }^{\mathrm{VI}, 1, \mathrm{~b}, *}$ \\
\hline & or many & & & & & Aggregata $^{\mathrm{I}, \mathrm{b}, * * *}$ \\
\hline
\end{tabular}

Predominance of parasitism in invertebrates ${ }^{\mathrm{I}}$, fish ${ }^{\mathrm{II}}$, amphibian ${ }^{\mathrm{III}}$, reptiles ${ }^{\mathrm{IV}}$, birds ${ }^{\mathrm{V}}$ and mammals ${ }^{\mathrm{VI}}$; Adeleid coccidia ${ }^{1}$ (Adeleorina); Eimeriid coccidia ${ }^{2}\left(\right.$ Eimeriorina: $^{2}$ Eimeriidae); and Tissue cyst-forming coccidia ${ }^{3}$ (Eimeriorina: Sarcocystidae); Presence of Stieda/substieda body ${ }^{\mathrm{a}}$ or sutures in sporocyst ${ }^{\mathrm{b}}$; Oocysts in kidney* ${ }^{*}$ liver** or mantle (Mollusca) $)^{* * *}$. 
Traditionally, Eimeriidae brings together various genera with distinct characteristics (DUSZYNSKI et al., 1999). However, Jirků et al. (2002), based on morphology and molecular phylogeny, considered that all Eimeriidae present a complex of Stieda and substieda bodies. Based upon those affirmations, the genera Tyzzeria, Pfeifferinella, Caryospora of raptors, Choleoeimeria, Acroeimeria, Goussia, Barroussia, Pseudoklossia and Aggregata are no longer considered as members of the Eimeriidae, and have been included in other families.

Tyzzeria and Pfeifferinella have octozoic oocysts without sporocysts. Tyzzeria is a intestinal parasite of Anseriformes; while, Pfeifferinella is parasite of the digestive gland (liver) of Gastropoda. The presence of a 'vaginal tube' in macrogametes of some species of Pfeifferinella also clearly distinguishes it from Tyzzeria (WENYON, 1926; ALLEN, 1936; WACHA, 1980; FRITSCHE, 1987; DUSZYNSKI et al., 1999; BERTO et al., 2007, 2008e; McALLISTER, 2013). Levine (1982) had considered the family Pfeifferinellidae, which could contain these two genera; however, Wacha (1980) demonstrated differences in macrogametes of Pfeifferinella, which contained 1 to 5 peripherally located nucleoli, whereas in Tyzzeria they showed a single, relatively large, centrally located nucleolus typical of macrogametes of Eimeriidae. These observations serve to complicate the elucidation of the taxonomic position of these genera.

Caryospora is the only traditional Eimeriidae with a facultative heteroxenous life cycle. Furthermore, the Caryospora spp. of reptiles show a complex of Stieda and substieda bodies, while the Caryospora spp. of raptors lack this feature. In this context, Barta et al. (2001) showed Caryospora and Lankesterella to be closely related based upon molecular phylogeny and in light of some common aspects of their life cycles. In rodents, Caryospora forms thin-walled oocysts in the facial dermis, which rupture releasing sporozoites that form the caryocyst. In Lankesterella sporozoites are also released from thin-walled oocysts, they invade blood cells that can subsequently be transported to other susceptible hosts via hematophagous invertebrates. Furthermore, these two genera were placed in the same clade by molecular phylogeny. These observations suggested that, the family Lankesterellidae could include the genera Schellackia, Lankesterella, Lainsonia and Caryospora (BARTA et al., 2001; JIRKU゚ et al., 2002).

Choleoeimeria and Acroeimeria are tetrasporic dizoic parasites of reptiles; with Choleoeimeria parasitizing the biliary epithelial cells while Acroeimeria is an epicytoplasmic parasite of intestinal cells (PAPERNA; LAINSON, 1999; MODRÝ; JIRKU゚, 2006; AL-QURAISHY, 2011). Goussia has oocysts with variable numbers of dizoic sporocysts being reported from fish and amphibians. Morphological data in combination with molecular phylogeny highlighted the similarity of these genera to Barroussia, which are parasites of invertebrates. Choleoeimeria, Acroeimeria, Goussia and Barroussia each have a sporocyst wall composed of two plates joined by a longitudinal suture. The possession of this highly distinctive feature would provide the basis for the resurrection of Barroussidae as proposed by Levine (1983), which would combine the four genera into a single family (JIRKU゚ et al., 2002).

Pseudoklossia has oocysts with many dizoic sporocysts and generally occurs in the kidney of marine molluscs. This genus was included in Aggregatidae along with Aggregata which is also a parasite of marine molluscs. However, Aggregata demonstrates polisporic polizoic oocysts that are trapped in the mantle and shows a heteroxenous life cycle, developing merogony in marine arthropods (WENYON, 1926; FRIEDMAN et al., 1995; MLADINEO; BOČINA, 2007; DUSZYNSKI et al., 1999).

The only genera classified in Eimeriidae, based upon their having a complex of Stieda and substieda bodies, and under some conditions a parastieda body as an excystation structure, are: Eimeria, Isospora and Cyclospora (JIRKUं et al., 2002). Eimeria is the genus with the largest biodiversity in Eucoccidiorida, being reported from invertebrates and all classes of vertebrates. The species of Eimeriidae are mainly intestinal, although some species develop in tissues including the liver, spleen and lungs (e.g. Isospora serini; Eimeria reichenowi); renal tubules (e.g. Eimeria truncata); liver and bile ducts (e.g. Cyclospora talpae; Eimeria stiedae); and the uterus (e.g. Eimeria neitzi) (McCULLY et al., 1970; OWEN, 1970; BOX, 1981; ENTZEROTH et al., 1981; NOVILLA et al., 1981; GARDINER et al., 1998; ROSALES; MASCARO, 1999).

Finally, Sarcocystidae comprises coccidia with facultative heteroxenous life cycles, forming cysts in intermediate hosts. The morphology and location of the cysts, as well as some pathological features and susceptible host range, are crucial for differentiation of species (ODENING, 1998). Many genera are incuded in this family, including recently identified genera (Nephroisospora), resurrected genera (Hyaloklossia) and some genera considered as controversial because they are paraphyletic and/ or have biological and morphological similarities (Toxoplasma, Neospora and Hammondia) (ELLIS et al., 1999; FRENKEL; DUBEY, 2000; MEHLHORN; HEYDORN, 2000; MODRÝ et al., 2001; DUBEY et al., 2002; WÜNSCHMANN et al., 2010). Regarding the characteristics of oocysts, the main synapomorphy of this family is the sporocyst wall that is composed of four plates joined by sutures. As a result, the tissue cyst-forming coccidia do not present a complex of Stieda and substieda bodies (JIRKUீ et al., 2002). Indeed, it was this distinction that supported the relocation of mammalian Isospora to Sarcocystidae, and the resurrection of Cystoisospora (e.g. Cystoisospora suis, Cystoisospora rivolta, Cystoisospora ohioensis, Cystoisospora belli, etc.) (BARTA et al., 2005; SAMARASINGHE et al., 2008)

\section{Morphological Studies}

The main morphological features of sporulated oocysts of coccidia are presented in Figure 1. The drawing represents an Eimeria, which, like the other Eimeriidae, has a complex of Stieda and substieda bodies as well as additional features that may facilitate the identification and characterization of species. The other coccidia which have plates joined by sutures, posterior extensions, sporopodia or that lack sporocysts, can also be identified based upon their oocyst morphology, although this is considered to be more difficult. The sections which follow provide information in relation to the principal structures that should be observed and characterized. 

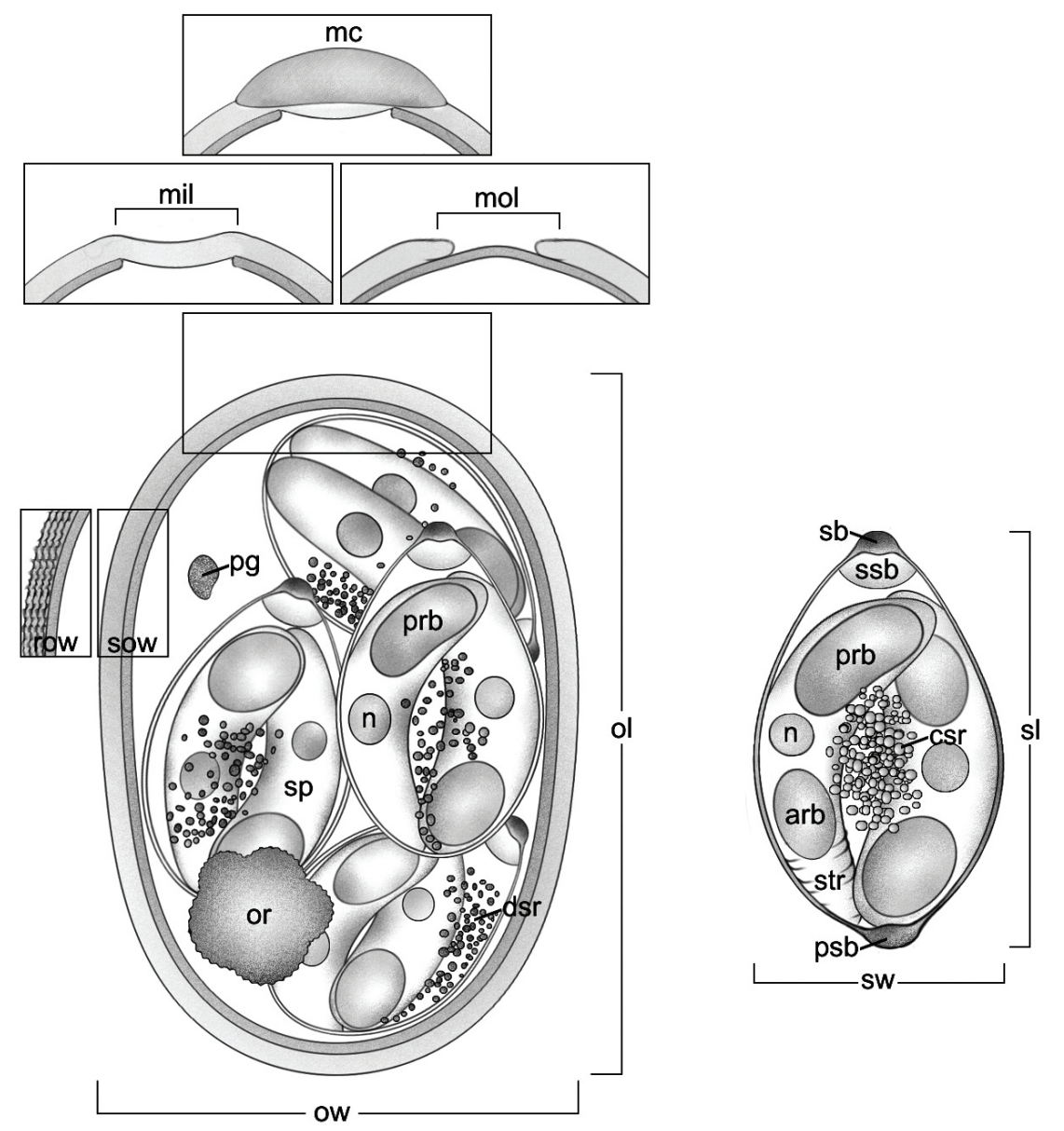

Figure 1. Line drawing of a sporulated oocyst (Apicomplexa: Eucoccidiorida: Eimeriidae) detailing the main structures that must be observed, measured and characterized, which are: (ow) oocyst width; (ol) oocyst length; (pg) polar granule; (or) oocyst residuum; (row) rough or (sow) smooth outer wall; micropyle in (mil) inner layer or (mol) outer layer; (mc) micropyle cap; (sw) sporocyst width; (sl) sporocyst length; (sb) Stieda body; (ssb) substieda body; (psb) parastieda body; (csr) compact or (dsr) diffuse sporocyst residuum; (sp) sporozoite; (prb) posterior and (arb) anterior refractile body of the sporozoite; (n) sporozoite nucleus; and (str), sporozoite striations.

\section{Oocyst wall}

The studies of Belli et al. (2006) and Mai et al. (2009) suggested that the basic structure of the oocyst wall is consistent across the coccidia. In both studies the authors convincingly demonstrated that the oocyst wall is comprised of two distinct layers, surrounded by an outer membrane, termed the outer veil, which is normally absent in mature oocysts isolated from feces. The bi-layer model is at odds with many earlier studies which considered oocysts with single-layered walls in their descriptions (LAINSON; SHAW, 1989; LOPES et al., 2014). Indeed, possession of a single layered wall forms a component of the guidelines for the preparation of species descriptions in the Eimeridae developed by Duszynski and Wilber (1997). Yet, it is currently believed that the single-layered walls described from some coccidia, were in fact double-layered with very thin and/ or fused layers, which hampered their correct observation by light microscopy (BELLI et al., 2006; MAI et al., 2009).

An additional important feature used in the description of the oocyst wall is the color. Many authors describe and differentiate species based on the color of the wall, characterizing them as brown, yellowish, brownish, etc. (e.g. Eimeria spp. from swine) (DAUGSCHIES et al., 1999; BENNETT; HOBBS, 2011; ALFALEH et al., 2013), however in some cases it is pertinent to note that these colors may be artifactual, resulting from differences in the exposure time of the oocysts to preservatives (e.g. potassium dichromate), the light intensity or the choice of filter used for light microscopy (NOWELL; HIGGS, 1989). On the other hand, the difference in tonality between the two layers, considered as darker and lighter, can be an important feature in some cases (e.g. Eimeria leuckarti) (DE SOUZA et al., 2009).

The texture of the outer surface of the oocyst wall, which can vary from smooth (sow, Figure 1) to rough (row, Figure 1), is considered an important feature that, in some cases, allows differentiation between closely related Eimeria spp. (e.g. Eimeria trinidadensis; Eimeria ichiloensis; Eimeria boliviensis) (CASAS et al., 1995; ALBUQUERQUE et al., 2008). This feature is best observed, and consequently more accurately described, when the focus of the light microscope is placed on the outer surface of the oocyst wall, as described for Eimeria philanderi and Eimeria caluromydis by Lainson and Shaw (1989). In the case of Isospora the texture of the outer surface of the oocyst wall is predominantly smooth, 
which effectively negates the use of this characteristic for species differentiation (BERTO et al., 2011a, b). Finally, the presence of protruding structures on the outer surface of the oocyst, described as spines or conical projections, has been reported for some species (e.g. Eimeria stylosa; Eimeria mitraria) (McALLISTER; UPTON, 1989; ŠIROKÝ; MODRÝ, 2006)

\section{Micropyle and micropyle cap}

The micropyle can be defined as a discontinuity in one of the layers of the oocyst wall. This feature can be observed in the inner layer (mil, Figure 1) (e.g. Eimeria bareillyi; Eimeria dorcadis) (RAMIREZ et al., 2009a; MOHAMMED et al., 2012) or outer layer (mol, Figure 1) (e.g. Eimeria leuckarti) (de SOUZA et al., 2009). In some coccidian species (e.g. Eimeria minasensis), the micropyle appears to be covered by a cap, the micropyle cap (mc, Figure 1), that is considered to provide protection for discontinuous regions of the layers (SILVA; DIVINO-LIMA, 1998; ARSLAN et al., 2002; TURNER et al., 2012). These structures are common in Eimeria, but uncommon or absent in other genera. Interestingly, Wacha (1980), Fritsche (1987) and, more recently, McAllister (2013) reported micropyle in Pfeifferinella gugleri, however the morphological structure was not described in detailed in those studies.

\section{Oocyst residuum and polar granule}

The oocyst residuum (or, Figure 1) comprises a large structure within the oocysts, located between the sporocysts. This structure may be comprised of a regular and compact mass (e.g. Eimeria heliophobii; Eimeria yamikamiae) or it may be formed by an irregular mass of granules (e.g. Eimeria stiedai; Eimeria media; Eimeria intestinalis) (MODRÝ et al., 2005; EL-SHAHAWI et al., 2012).

The polar granule (pg, Figure 1) is an additional internal structure of the oocysts, also located between the sporocysts; however, this is smaller than the oocyst residuum and invariably dense (e.g. Eimeria spp. from Japanese quails). The format of this structure can be unique in many species, and may present a variety of characteristic shapes including splinter-like and comma-like (e.g. Isospora frontalis) (BERTO et al., 2009d, 2013b).

\section{Complex of Stieda and substieda bodies}

The work of Grulet et al. (1982) revealed the importance of the Stieda (sb, Figure 1) and substieda (ssb, Figure 1) bodies for the accurate diagnosis and description of Isospora spp. In that study, 12 new species were described from the domestic sparrow Passer domesticus, with variation in the Stieda and substieda bodies providing the basis for their differentiation. The utility of those structures to facilitate the identification of Isospora has been clearly demonstarted via numerous descriptions of new species, where variation in the Stieda and substieda bodies were recorded as a key morphological trait (UPTON et al., 1985, 1988; McQUISTION; HOLMES, 1988; LAINSON; SHAW, 1989; UPTON et al., 1995; McQUISTION; CAPPARELLA, 1997; UPTON; WHITAKER,
2000; BERTO et al., 2008a-d, f, 2009a-f, 2010b, d, 2011b, c, 2013a BALTHAZAR et al., 2009b; COELHO et al., 2011a, b, 2013; PEREIRA et al., 2011).

The size and shape of Stieda and substieda bodies in the sporocysts show a characteristic pattern for each Isospora sp; therefore, in the majority of cases the performance of a detailed description should be sufficient to arrive at a species level identification. Given the importance of this structure it is recommended that, whenever possible, variations observed by light microscopy for representatives of the same species must be characterized and drawn. Possible reasons for such variations include the position of the sporozoites within the sporocyst, or the position of the oocyst and sporocyst under the coverslip. In this context, these variations are likely to be subtle and may possibly be observed in sporocysts of a single oocyst. However, if these variations are evident in distinct oocysts, it is possible that the host contains two different species, as was described by Berto et al. (2011c) for Isospora coerebae and Isospora cagasebi from bananaquits Coereba flaveola (BERTO et al., 2008a-d, f, 2009a-f, 2010b, d, 2011b, c, 2013a; BALTHAZAR et al., 2009b; COELHO et al., 2011a, b, 2013; PEREIRA et al., 2011).

Figure 2 illustrates and provides suggestions for denominations for the main types and shapes of Stieda and substieda bodies that have previously been described in the literature. The nomenclature employed herein, is different from that used in some studies. However, it attempts to bring together the terminologies that are most widely employed for describing these structures. As such, it is hoped that this figure will serve as a guideline for classifying Stieda and substieda bodies, and that it may help to avoid discrepancies between future studies. Additionaly, it should be noted that some features, including filaments; fine membranous cup-like formations; club-shaped projections; etc, have been reported in association with the Stieda body and these must be characterized (e.g. Eimeria pangshurae; Eimeria arakanensis; Eimeria emydis) (SEGADE et al., 2006; ŠIROKÝ; MODRÝ, 2010).

The importance of the substieda body has traditionally been associated with Isospora spp.; however, recent studies have emphasized its potential value for the identification and diagnosis of Eimeria spp. (RAMIREZ et al., 2008a; BERTO et al., 2008g, 2009a, 2013b; HOFSTATTER; KAWAZOE, 2011; CHINCHILLA et al., 2013). In this context, the redescription of some species has been proposed based upon the observation of a substieda body in their sporocysts (BERTO et al., 2013b). Moreover, Berto et al. (2013b) proposed an algorithm, wherein the substieda body is one of the main characteristic features used in the formula, which enabled reliable identification of individual species of Eimeria during routine diagnosis of pathogens of the Japanese quail Coturnix japonica. In common with those workers, we consider this structure to be of immense importance for differential diagnosis and species identification of Eimeria in general.

\section{Parastieda body}

The parastieda body (psb, Figure 1) has been described infrequently in coccidia. Duszynski (1985) and Duszynski and Wilber (1997) observed and characterized this structure in Eimeria parastiedica as representing a substieda body located at the opposite 


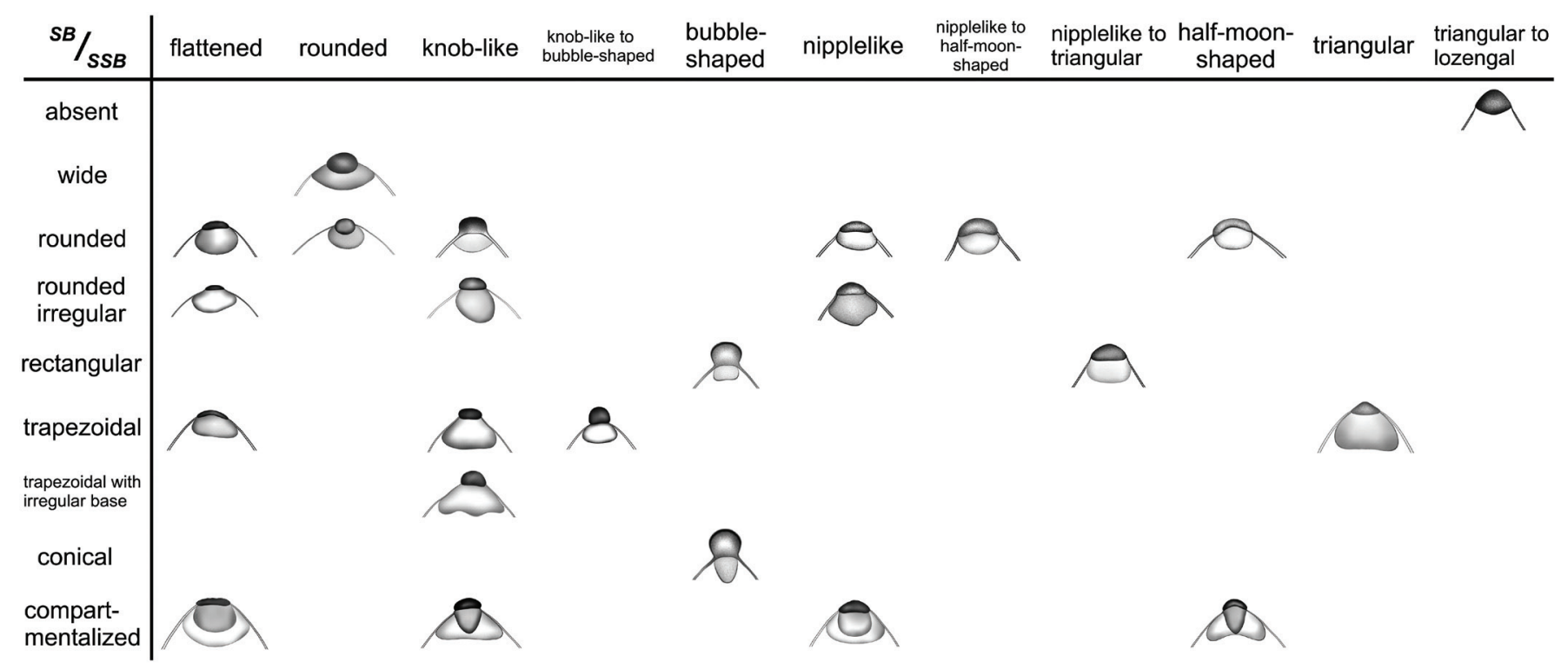

Figure 2. Line drawings of several complexes of Stieda and substieda bodies with suggestions of terms to be used for morphological description [adapted from Grulet et al. (1982), Berto et al. (2009a-c, e, f, 2010b, 2011b, c, 2013a, b), Balthazar et al. (2009b), Pereira et al. (2011) and Coelho et al. (2011a, b, 2013)].

end of the oocyst relative to the Stieda body. More recently, in a study of Eimeria caviae, Flausino et al. (2014) reported the presence of a parastieda body and considered it as a structure resembling an additional Stieda body, located at the opposite end of the oocyst, which served to complicate the localization of the anterior and posterior ends.

\section{Sporocyst residuum}

The sporocyst residuum can be quantified relatively in each coccidian species and a description of this structure is a component of most species descriptions. The structure may appear as being diffuse among sporozoites (dsr, Figure 1) (e.g. Eimeria sicki; Isospora teresopoliensis) or it can form a compact mass of granules (csr, Figure 1) (e.g. Isospora mionectesi; Isospora chanchaoi). In some cases, the compact mass may be surrounded by a membrane (e.g. Isospora paranaensis); while in other species, a distinct pattern is observed as the granules develop a characteristic ring form (e.g. Isospora navarroi) (SILVA et al., 2006; BERTO et al., 2009a, b, d, f, 2011a; LOPES et al., 2013).

\section{Sporozoites}

The structures associated with the sporozoite are the refractile bodies (rb, Figure 1), the nucleus (n, Figure 1) and striations (str, Figure 1). The refractile bodies may be unique to each sporozoite (e.g. Isospora marambaiensis; Eimeria bateri), or may appear as a pair, one anterior (arb, Figure 1) and one posterior (prb, Figure 1) (e.g. Isospora trincaferri; Isospora massardi), and may be sub-spherical (e.g. Isospora trincaferri) to elongated (e.g. Isospora marambaiensis) in shape. The nucleus is generally smaller than the refractile bodies and is located in the center of the sporozoite (e.g. Isospora sayacae; Eimeria bateri). In some cases, striations are observed at the anterior end of the sporozoite (e.g. Isospora sayacae) (BERTO et al., 2008d, 2009e, f, 2013a; LOPES et al., 2014)

\section{Morphometrical Studies}

All of the structures mentioned above can be measured for the characterization of oocysts of a coccidian species. However, the features which are most commonly taken into consideration are the length (ol, Figure 1) and width (ow, Figure 1) of the oocyst, and the length (ol, Figure 1) and width (ow, Figure 1) of the sporocyst. In addition, measurements of the height and width of Stieda and substieda bodies are extremely relevant for Isospora, since these structures are prominent and highly discriminatory in this genus (DUSZYNSKI; WILBER, 1997; TENTER et al., 2002; BERTO et al., 2011a, b).

\section{Shape-index (Length/ Width ratio)}

The ratio of length over width (shape-index) is used to demonstrate the shape of the oocysts and sporocysts. In this ratio a value close to 1 denotes spheroid structures; therefore, spherical oocysts generally have shape-index equal to 1.0 ; sub-spherical oocysts have values between 1.0 to 1.1 , and oocysts within the 'ellipsoidal complex' provide values higher than 1.1. The term 'ellipsoidal complex' was introduced because oocysts with shapeindexes higher than 1.1 may be ellipsoidal (e.g. Eimeria bateri; Isospora mionectesi), ovoid (e.g. Eimeria bovis; Isospora sepetibensis), pear-shaped (e.g. Eimeria bareillyi; Eimeria anseris), bottle-shaped (e.g. Eimeria boschadis; Eimeria somateriae), etc. Therefore, the oocysts and/ or sporocysts with shape-indexes greater than 1.1 should always be described with attention given to their shape (LEVINE, 1985; SOULSBY, 1987; ARSLAN et al., 2002; BERTO et al., 2009b, 2011b, 2013a, b; FLAUSINO et al., 2014) 


\section{Histograms}

Statistical graphics can be produced targeting the morphometrics of the oocysts of a coccidian species in comparison with those of other species. The histograms plot the values of length, width and the shape-index of the oocysts, along with their frequencies within a sample (SAMPAIO, 2002; BERTO et al., 2011a, b, 2013b; HAUCK; HAFEZ, 2012; FLAUSINO et al., 2014).

This approach may serve to demonstrate tendencies and regularities in the distribution of the oocyst dimensions. Analysis of the data will reveal if the frequencies ascend and descend in the graph or if they simply ascend or descend linearly. Hence, histograms can confirm the presence of a single species in the oocyst sample; can determine the degree of polymorphism within that single species or can indicated the presence of multiple species. Figure 3, illustrates examples of regular (Figure 3a, c, e) and irregular (Figure 3b, d, f) histograms that suggest the presence of one (Figure 3a-d) or two species in the sample (Figure 3e, f) (BERTO et al., 2011a, b, 2013b; HAUCK; HAFEZ, 2012; FLAUSINO et al., 2014).

The histogram of shape-index (Figure $3 \mathrm{~h}$ ), is provided in an attempt to demonstrate the tendency of shape of the oocysts of a species. For example, a given species may have sub-spherical to ellipsoidal oocysts with shape-indexes ranging from 1.0 to 1.3 , but the histogram may insert $95 \%$ of the oocysts in class 1.0 to 1.1 demonstrating a tendency towards a sub-spherical shape, with a limited number of the oocysts being ellipsoidal. The counter example may also occur whereby most of the oocysts would be inserted in the class of 1.1 to 1.3 , revealing another species with the same range of shape-indexes, but demonstrating a different tendency (BERTO et al., 2011b).

Additionaly, histograms can be produced to identify species with no morphological differences, but with possible morphometrical tendencies. In this way, Cardozo et al. (2013) compared Cryptosporidium oocysts recovered from mussels with oocysts of Cryptosporidium hominis.

More recently, some researchers have produced histograms of length and width superimposed in the graph as shown in Figure $3 \mathrm{~g}$. This method has the advantage of providing more detailed observations, permiting confirmation of the shape-index by observing the proximity between the more frequent classes and their respective values (BERTO et al., 2013b; FLAUSINO et al., 2014).

\section{Linear regression}

Linear regression analyses of plot measurements of width on length of oocysts (Figure 4), is a long established statistical method that can be used to relate measurements of oocysts of the same or different species and hosts (NORTON; JOYNER, 1981; MEIRELES; FIGUEIREDO, 1992; HASSUM et al., 2007; COSENDEY et al., 2008; BERTO et al. 2008g, h, 2011a, 2013b; HAUCK; HAFEZ, 2012; FLAUSINO et al., 2014).

In this method the measurements of width are arranged in the $\mathrm{Y}$ axis and the measurements of length in the $\mathrm{X}$ axis. In the graphs, the line regression, the datapoints, the $\mathrm{R}^{2}$ (coefficient of determination) value and the coefficient of the regression line must be presented. The $\mathrm{R}^{2}$ value provides most of the meaningful observations derived from the linear regression. Thus, when $\mathrm{R}^{2}$ values are higher than 0.5 the data points are distributed close to the regression line on the graph, which serves to demonstrate slight variations of width over length and, therefore, a clear pattern can be established for this species. In contrast, $\mathrm{R}^{2}$ value lower than 0.5 will result in a distribution of data points distant from the regression line, indicating polymorphism within the oocyst sample (SAMPAIO, 2002; HASSUM et al., 2007; BERTO et al., 2008g, h, 2011a, b, 2013b; HAUCK; HAFEZ, 2012; FLAUSINO et al., 2014).

In this context, polymorphism consists of low values for the proportionality of width on length, and does not necessarily infer the presence of more than one species among oocysts measured, or failure in the measurement process. It is important to note, that oocyst polymorphism has been described previously by several authors for a variety of coccidia, and is considered to be related to factors including: (1) stress; (2) nutrition; (3) immunity of the host; (4) the infecting dose; (5) the timing of oocysts discharge during the patent period; (6) substance in which and period that the oocysts were stored; and (7) phenotypic plasticity, described as the ability of a coccidium to adopt different phenotypes in response to its environment (DUSZYNSKI, 1971; CATCHPOLE et al., 1975; JOYNER, 1982; FAYER, 1980; GOMEZ et al., 1982; PARKER; DUSZYNSKI, 1986; GARDNER; DUSZYNKI, 1990; BERTO et al., 2008h, 2011b; RAMIREZ et al., 2009a, b; FLAUSINO et al., 2014).

An additional phenomenon worthy of mention is the increased possibility of polymorphism in oocysts which demonstrate shapeindex values higher than 1.1, and which belong to the 'ellipsoidal complex'. It should be remembered, that the oocyst is a threedimensional form which is measured two-dimensionally, under an optical microscope. The ellipsoidal oocyst, depending on its position under the cover slip (i.e. the angle of observation) may appear as spherical to ellipsoidal, while the spherical oocyst, regardless of the position under cover slip will always has the same dimensions. That being the case, the ellipsoidal oocysts must be measured only when positioned lengthwise. To meet this prerequisite, the coverslip may be gently maneuvered to move the oocyst such that it will reveal its true position and shape (BERTO et al., 2011b).

The primary use of linear regression is to evaluate the measurements of oocysts of a single species. However, it may also be of value in situations where different host-species shed oocysts of the same coccidian-species or when a host-species shed oocysts of different coccidian-species. In such cases, the linear regressions must be performed for each host/coccidium, with the data being superimposed within the graph. Here, the relative positions of the lines on the same graph can provide some valuable results. In the case of studies reporting a new host, regression lines which are close to or that overlap the line(s) produced by analysis of oocysts recovered from a previously established host(s) will provide support for the definition of the new host. Alternatively, in studies comparing oocysts of different species comparison of regression lines can reveal a variety of differential features: (1) ranges, in accordance with the length of the regression lines; (2) size, here larger oocysts will be recorded higher and more to the right in the 

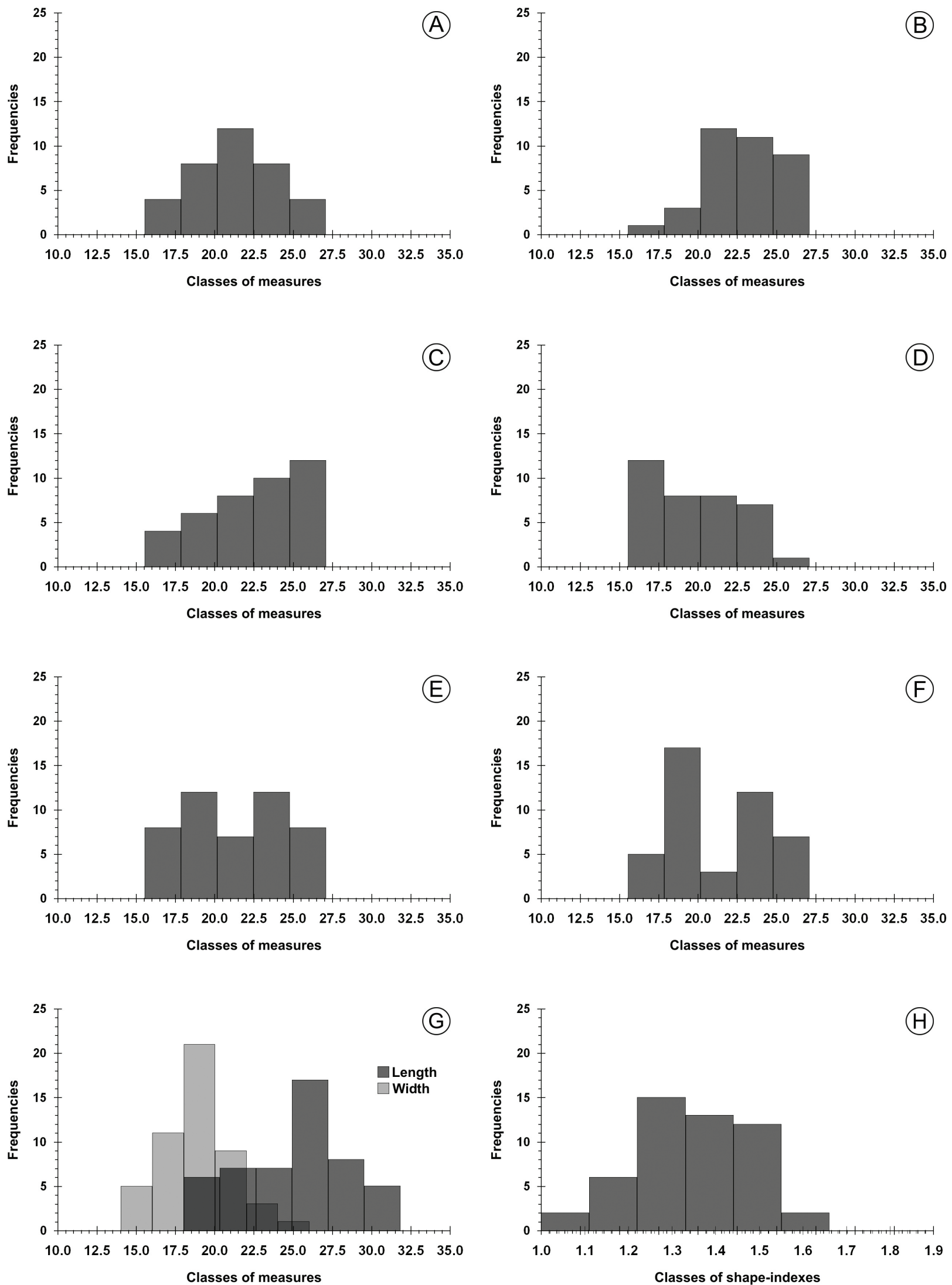

Figure 3. Examples of histograms which demonstrate (A, C, E) regular and (B, D, F) irregular distribution and suggest (A, B, C, D) one or (E, F) two coccidian-species. Histograms of length and width can be superimposed in the graph providing more detailed observations, as in histogram $(G)$ that reveals tendencies in the dimensions 24.7-27.2 $\times 18.0-20.0$, which is evidenced in $(\mathrm{H})$ a histogram of shape-index that has higher frequency in the classes of 1.22 to 1.55 [adapted from Berto et al. (2013b)]. 
graph; and (3) shape, sub-spherical oocysts generate regression lines with a greater gradient of slope (Figure 4) (HASSUM et al., 2007; BERTO et al., 2008g, h, 2011b).

Finaly, linear regression provides a basis by which to evaluate whether one or more methods (e.g. collection medium, preservative, staining methods) alter the morphometry of oocysts (RAMIREZ et al., 2008b)

\section{Mean comparison tests}

It is recommended that Analysis of variance (ANOVA), Student's t-test or other mean comparison tests should be used to compare measurements of length, width and shape-index of oocysts and sporocysts. In some cases, these methods may be used to compare mean measurements of specific structures considered relevant to identification, such as the Stieda and substieda bodies (BERTO et al., 2011c). The mean comparison tests may also be utilized to compare additional, quantitative parameters determined for the specific oocysts under investigation. As an example, Berto et al. (2013b) employed ANOVA to compare the values of an algorithm developed for the identification of coccidian parasites of Japanese quails. In general, these types of mean comparison tests are used for comparing coccidian species recovered from

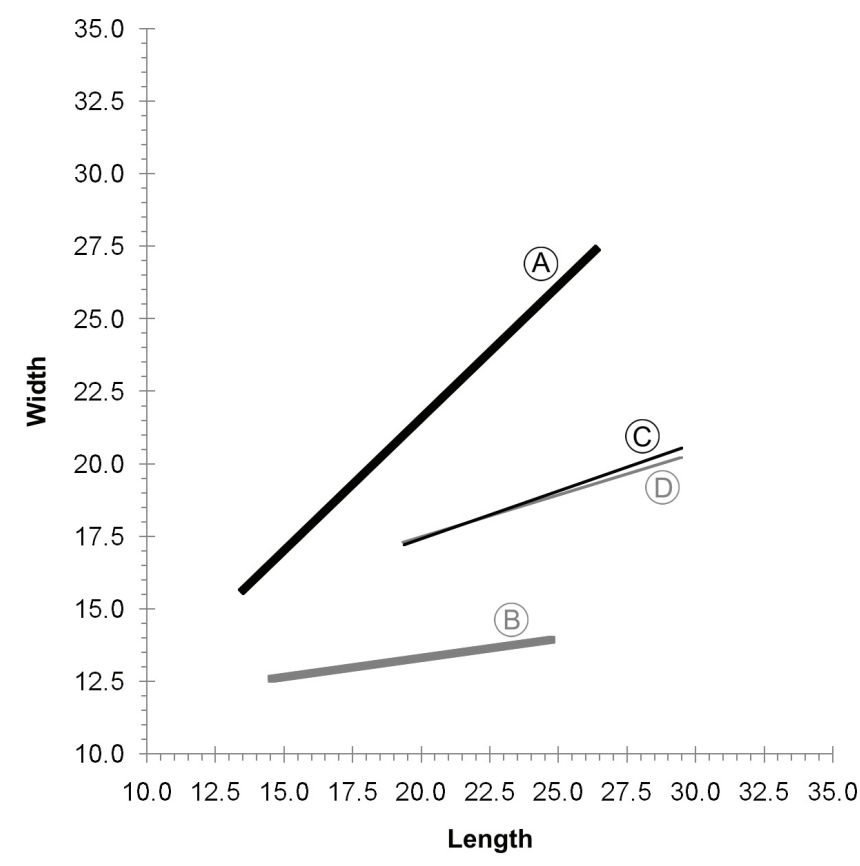

Figure 4. Example of linear regressions superimposed in a single graph. The thick and black regression line (A) represents a coccidianspecies with larger oocysts, higher range and sub-spherical shape as indicated by its superior position, increased line length and slope. The thick and gray regression line (B) represents a coccidian-species with smaller oocysts, lower range and an ellipsoidal shape as inferred by its inferior position, lower line length and slope. The thin regression lines $(C, D)$ may represent the same coccidian-species or possibly different coccidian-species with similar length and width of oocysts. In this type of situation, it would be necessary to examine additional morphological and morphometric parameters in order to differentiate the coccidia. the same host/family or alternatively they may be employed for comparing the same coccidian species recovered from different host species (GOMEZ et al., 1982; BALTHAZAR et al., 2009a; BERTO et al., 2008g, h, 2010c, 2011a, b, 2013b)

\section{Molecular biology}

An analysis of recent literature dealing with the detection, systematics and taxonomy of the coccidia reveals that, in common with numerous other areas of parasitology and microbiology, the application of molecular methods has steadily increased since the mid 90's and is now a firmly established practice, particularly with regard to the coccidian parasites of production animals (CARVALHO et al., 2011; CHAPMAN et al., 2013). The principal molecular method employed is the polymerase chain reaction (PCR), which can be used to amplify species specific DNA sequences for diagnostic purposes (OGEDENGBE et al., 2011a), or to amplify genus or family level molecular markers, with a "universal" distribution; including the nuclear $18 \mathrm{~S}$ rDNA locus (MORRISON et al., 2004), the internal transcribed spacer (ITS) regions (LEW et al., 2003 MOTRIUK-SMITH et al., 2011) or the gene (cox-1, COI), encoding the mitochondrial cytochrome c oxidase subunit I (OGEDENGBE et al., 2011b). Comparative nucleotide sequence analysis of the markers, involving the determination of nucleotide similarity to sequences derived from known species which are deposited in public databanks e.g. GenBank, can generate genus or species level identification of the parasites, lend support to the establishment of new species and may provide the basis for molecular phylogenetic studies.

The performance of these methods is not technically demanding, which has served to make them widely accessable. Yet, in contrast, it has become apparent that interpretation of the growing body of molecular data available for these parasites is not a straightforward process. A thought provoking overview of the complexities and shortcomings of molecular characterisation of the coccidia was recently produced by Chapman et al. (2013). Therein, the authors drew attention to the potential pitfalls of molecular characterization based on analysis of a single molecular marker, and provided topical examples as to why caution should be exercised when employing $18 \mathrm{~S}$ rDNA sequences for identification or in systematic studies. In this contex, recent reports of independently evolving paralogous copies of $18 \mathrm{~S}$ rDNA in the nuclear genome of the chicken coccidium Eimeria mitis (VRBA et al., 2011) and in the turkey coccidium E. meleagrimitis (EL-SHERRY et al., 2013), have served to question the reliability of using this sequence as a species level molecular marker for coccidia. In the case of $E$. mitis, the paralogous copies of $18 \mathrm{~S}$ rRNA showed $1.3-1.7 \%$ sequence divergence from the previously identified $18 \mathrm{~S}$ rDNA sequences of this species. However, these novel sequences were shown to be $99.3 \%$ to $99.5 \%$ similar to published sequences submitted under the name Eimeria mivati, a species described as morphologically indistinguishable from E.mitis. Vrba et al. (2011), concluded that $E$. mivati and E. mitis are almost certainly the same species and that the appearance of two species, based upon the observed differences in $18 \mathrm{~S}$ rDNA sequences, most likely occurred as a consequence of inadequate sampling. The levels of intra-specific 
sequence divergence, among paralogous copies of $E$. meleagrimitis $18 \mathrm{~S}$ rDNA, was even higher (approximately 2.6\%) than the values recorded for $E$. mitis. The implications of such intraspecies variation for species identification, becomes apparent when compared to the level of the interspecific sequence divergence (1.1\%) that is present between some well-recognized species such as Eimeria tenella and Eimeria necatrix (EL-SHERRY et al., 2013). It is important to note that the sequence variation was observed in DNA which had been extracted from single-oocyst-derived lines of the Eimeria species. Clearly the use of such lines, or alternatively of single isolated oocysts as reported by Dolnik et al. (2009), is to be highly recommended in order to provide the maximal level of confidence in the molecular data.

In an attempt to counterbalance the emerging problems associated with use of $18 \mathrm{~S}$ rDNA as a marker, a tendency has begun to emerge among researchers to employ the mitochondrial COI sequence as a complementary, or even as an alternative marker for species level identification (SCHWARZ et al., 2009; OGEDENGBE et al., 2011b; CHAPMAN et al., 2013; ELSHERRY et al., 2013). The utility of this marker has been firmly established in many areas of biology, and is at the heart of the Barcode of Life Project (iBOL.org), which aims to develop a molecular barcode-based identification system for animals, including parasites (RATNASINGHAM; HEBERT, 2007; OGEDENGBE et al., 2011b). The major disadvantage associated with the use of this maker is the fact that, at present, there exists a lack of coverge for coccidian COI sequences in public databases; however it is anticipated that this situation will improve as the advantages of this marker become established.

Continuing reductions in the costs associated with molecular based methods, particularly nucleotide sequencing, coupled with advances in the field of bioinformatics will likely stimulate the adoption of multi-maker, or even whole genome, sequencing as means through which to arrive at definitive identifications of coccidia (CHAPMAN et al., 2013). Sequencing of the complete mitochondrial genomes, comprising 3 genes for proteins (cox1, cox3, and cytb), 12 gene fragments for the large subunit (LSU) rRNA, and 7 gene fragments for the small subunit (SSU) rRNA, of six Eimeria species (E. acervulina, E. brunetti, E. maxima, E. necatrix, E. tenella and E. praecox) isolated from chickens was recently reported (LIN et al., 2011). The genomes which were approximately $6200 \mathrm{bp}$ in size, showed similar organization and A+T contents. Subsequent phylogenetic analyses perfomed using concatenated nucleotide sequences of 2 protein-coding genes (cytb and cox 1 ) of the 6 genomes with three different computational algorithms (Bayesian analysis, maximum parsimony and maximum likelihood), all revealed distinct groups with high statistical support, indicating that the six Eimeria spp. represent six distinct but closely-related species.

The application of molecular techniques to the study of well established and socio-economically important coccidian species has answered some old questions, but at the same time it has raised some new ones. Molecular methods seem set to play a growing role in the study of all coccidia, they hold the potential to produce highly precise insights into the biology of these parasites, particularly when used in combination with morphological and morphometric data as a component of a polyphasic approach.

\section{Diagnostic Tools}

In addition to PCR based diagnostics, dichotomous key and algorithms represent two tools that are especially useful for the differentiation and diagnosis of coccidia (SCOTT; DUSZYNSKI, 1997; DAUGSCHIES et al., 1999; HASSUM et al., 2007; BERTO et al., 2013b).

\section{Dichotomous key}

Dichotomous keys are compatible with data generated from the morphological characterization of coccidian-species. In this context, the presence, absence, shape, color, location, etc. of structures of the oocyst and sporocyst, which are qualitative data, support the preparation of dichotomies that may suggest a species (SCOTT; DUSZYNSKI, 1997; BERTO et al., 2010d). Although not widely adopted, the use of dichotomous keys is both recommended and encouraged in situations where differentiation of species is based almost exclusively upon morphological data.

Scott and Duszynski (1997) developed a dichotomous key for Eimeria spp. described from New World bats. Subsequently, Berto et al. (2010d) developed a dichotomous key for Isospora spp. described in tanagers in Central and South America, which are sympatric with most New World tanagers (BERTO; LOPES, 2013).

\section{Algorithms}

In contrast to the dichotomous keys, algorithms are most compatible with morphometrical data produced from coccidianspecies. Thus, size, proportions and characters that generate quantitative data, provide the basis for the development of a formula that results in a value which should fluctuate within a range suggestive of a species. It is important to note that qualitative data may also be inserted into algorithms; however, to do so, they must first be converted into a numerical format (DAUGSCHIES et al., 1999; HASSUM et al., 2007; BERTO et al., 2013b).

The complexity of the algorithm is directly proportional to the number of associated coccidian-species. As a result, hosts which can be infected by multiple coccidian-species may require more than one complex formula. In this context, Daugschies et al. (1999) implemented different algorithms for differentiation of porcine Eimeria spp. dividing seven species into groups. In contrast, in the study of Berto et al. (2013b) the three species identified in Japanese quails could be diagnosed using a single algorithm.

\section{Conclusion}

As demonstrated in this review there are several procedures, approaches and tools that can be employed for the identification and characterization of a coccidian-species based on its oocysts.

Clearly the choice of which method(s) to employ is the responsability of the scientist undertaking the research. In this context, it was not our intention to establish rigid guidelines for the description of all coccidian-species or to suggest that any given method is of greater or lesser value than another method; however 
when appropriate, for example for the establishment of new species, we consider that if it is practical to do so, oocysts should be characterized as completely as possible through a combination of techniques, for the objectives of facilitating identification and to form a solid basis for future studies.

Finally, it would be fair to affirm that establishing the characteristics of the oocysts is a pre-requisite of any study of the coccidia. Clearly, the application of histological methods that reveal details of the biology and pathogenicity, methods for experimental infection that confirm host susceptibility and determine parasite load, serological and molecular methods which uncover inter- and intra-specific differences and provide taxonomic adjustments must all be considered as highly relevant. However, such methods should be viewed as serving to complement the fundamental characterization of a coccidian-species based on its exogenous forms: the oocyst.

\section{Acknowledgements}

This study was supported by grants from the Fundação Carlos Chagas Filho de Amparo à Pesquisa do Estado do Rio de Janeiro (FAPERJ) to B. P. Berto (E-26/110.987/2013).

\section{References}

Al-Quraishy S. A new Choleoeimeria species (Apicomplexa: Eimeriidae) infecting the gall bladder of Scincus mitranus (Reptilia: Scincidae) in Saudi Arabia. J Parasitol 2011; 97(6): 1125-1128. PMid:21612416. http://dx.doi.org/10.1645/GE-2790.1

Albuquerque GR, Berto BP, Catenacci L, Nogueira SSC, Nogueira-Filho SLG, Lopes CWG. Eimerid coccidia from capybaras (Hydrochoerus hydrochaeris) in southern Bahia, Brazil. Pesq Vet Bras 2008; 28(7): 323328. http://dx.doi.org/10.1590/S0100-736X2008000700001

Albuquerque MC, Brasil-Sato MC. First report of Calyptospora sp. (Apicomplexa, Calyptosporidae) in forage characid fish from the Três Marias Reservoir, São Francisco Basin, Brazil. Eur J Protistol 2010; 46(2): 150-152. PMid:20163938. http://dx.doi. org/10.1016/j.ejop.2009.12.005

Alfaleh FA, Alyousif MS, Al-Shawa YR, Al-Quraishy S. Caryospora cherrughi sp. n. (Apicomplexa: Eimeriidae) infecting Falco cherrug in Saudi Arabia. Parasitol Res 2013; 112(3): 971-974. PMid:23224640. http://dx.doi.org/10.1007/s00436-012-3217-y

Allen EA. Tyzzeria perniciosa gen. et sp. nov., a coccidium from the small intestine of Pekin Duck, Anas domesticus L. Arch Protistenkunde 1936; 87(1): 262-267.

Arslan MO, Gicik Y, Ozcan K. The frequency of Eimeriidae species in the domestic geese in Kars Province of Turkey. Acta Protozool 2002; 41(4): 353-357.

Balthazar LMC, Berto BP, Flausino W, Lopes CWG. The slate-colored seedeater, Sporophila schistacea, a new host for Isospora chanchaoi. Rev Bras Med Vet 2009a; 31(4): 253-255.

Balthazar LMC, Berto BP, Flausino W, Lopes CWG. Isospora ticoticoi n. sp. (Apicomplexa: Eimeriidae) from the rufous-collared sparrow Zonotrichia capensis in South America. Acta Protozool 2009b; 48(4): $345-$ 349.
Barta J, Martin DS, Carreno RA, Siddall ME, Profous-Juchelkat H, Hozza M, et al. Molecular phylogeny of the other tissue coccidia: Lankesterella and Caryospora. J Parasitol 2001; 87(1): 121-127. PMid:11227876.

Barta JR, Schrenzel MD, Carreno R, Rideout BA. The genus Atoxoplasma (Garnham 1950) as a junior objective synonym of the genus Isospora (Schneider 1881) species infecting birds and resurrection of Cystoisospora (Frenkel 1977) as the correct genus for Isospora species infecting mammals. J Parasitol 2005; 91(3): 726-727. PMid:16108579. http:// dx.doi.org/10.1645/GE-3341.1

Barta JR, Thompson RC. What is Cryptosporidium? Reappraising its biology and phylogenetic affinities. Trends Parasitol 2006; 22(10): 463468. PMid:16904941. http://dx.doi.org/10.1016/j.pt.2006.08.001

Barta JR, Ogedengbe JD, Martin DS, Smith TG. Phylogenetic position of the adeleorinid coccidia (Myzozoa, Apicomplexa, Coccidia, Eucoccidiorida, Adeleorina) inferred using $18 \mathrm{~S}$ rDNA sequences. $J$ Eukaryot Microbiol 2012; 59(2): 171-180. PMid:22313415. http:// dx.doi.org/10.1111/j.1550-7408.2011.00607.x

Belli SI, Smith NC, Ferguson DJ. The coccidian oocyst: a tough nut to crack! Trends Parasitol 2006; 22(9): 416-423. PMid:16859995. http:// dx.doi.org/10.1016/j.pt.2006.07.004

Bennett MD, Hobbs RP. A New Eimeria species parasitic in Isoodon obesulus (Marsupialia: Peramelidae) in Western Australia. I Parasitol 2011; 97(6): 1129-1131. PMid:21711101. http://dx.doi. org/10.1645/GE-2835.1

Berto BP, Teixeira M, Lopes CWG. Tyzzeria parvula (Kotlan, 1933) Klimes, 1963 (Apicomplexa: Eimeriidae) in the greylag goose (Anser anser Linnaeus, 1758) in Southeastern Brazil. Rev Bras Parasitol Vet 2007; 16(3): 156-158. PMid:18078603. http://dx.doi.org/10.1590/ S1984-29612007000300008

Berto BP, Flausino W, Luz HR, Ferreira I, Lopes CWG. Three New Coccidian Parasites of Brazilian Tanager (Ramphocelus bresilius dorsalis) from South America. Acta Protozool 2008a; 47(1): 77-81.

Berto BP, Flausino W, Luz HR, Ferreira I, Lopes CWG. Isospora cagasebi sp. nov. (Apicomplexa, Eimeriidae) from the bananaquit, Coereba flaveola of Brazil. Acta Parasitol 2008b; 53(2): 117-119. http://dx.doi. org/10.2478/s11686-008-0025-8

Berto BP, Flausino W, Ferreira I, Lopes CWG. Eimeria divinolimai sp. n. (Apicomplexa: Eimeriidae) in the rufous casiornis Casiornis rufus Vieillot, 1816 (Passeriformes: Tyrannidae) in Brazil. Rev Bras Parasitol Vet 2008c; 17(1): 33-35. PMid:18554438.

Berto BP, Balthazar LMC, Flausino W, Lopes CWG. Two new coccidian parasites of green-winged saltator (Saltator similis) from South America. Acta Protozool 2008d; 47(3): 263-267.

Berto BP, Flausino W, Lopes CWG. First report of Tyzzeria parvula (Kotlán, 1933) Klimes, 1963 (Apicomplexa: Eimeriidae) in Swan Goose Anser cygnoides L., 1758 in Brazil. Rev Bras Parasitol Vet 2008e; 17(S1): 326-328. PMid:20059870.

Berto BP, Lopes B, Flausino W, Teixeira-Filho WL, Lopes CWG. Contribution on the study of Isospora hemidactyli Carini, 1936 and a report of an adeleid pseudoparasite of the house gecko Hemidactylus mabouia, from the Rio de Janeiro Metropolitan Region, Brazil. Rev Bras Parasitol Vet 2008f; 17(3): 150-154. PMid:19245761.

Berto BP, Cardozo SV, Teixeira-Filho WL, Ferreira AMR, Lopes CWG. Aflatoxin effect on the oocysts morphometry and contribution on the morphology of Eimeria bateri Bhatia, Pandey and Pande, 1965 of the Japanese quail Coturnix japonica, in Brazil. Rev Bras Parasitol Vet 2008g; 17(4): 235-238. PMid:19265584. 
Berto BP, Flausino W, Almeida CRR, Lopes CWG. Polymorphism of Tyzzeria parvula (Kotlán, 1933) Klimes, 1963 (Apicomplexa: Eimeriidae) oocysts from the greylag geese Anser anser L., 1758 from two distinct sites. Rev Bras Med Vet 2008h; 30(4): 215-219.

Berto BP, Luz HR, Flausino W, Ferreira I, Lopes CWG. New species of Eimeria Schneider, 1875 and Isospora Schneider, 1881 (Apicomplexa: Eimeriidae) from the short-crested flycatcher Myiarchus ferox (Gmelin) (Passeriformes: Tyrannidae) in South America. Syst Parasitol 2009a; 74(1): 75-80. PMid:19633934. http://dx.doi. org/10.1007/s11230-009-9197-3

Berto BP, Flausino W, Luz HR, Ferreira I, Lopes CWG. Isospora mionectesi sp. nov. (Apicomplexa, Eimeriidae) from the grey-hooded flycatcher, Mionectes rufiventris in Brazil. Acta Parasitol 2009b; 54(4): 301-304. http://dx.doi.org/10.2478/s11686-009-0053-z

Berto BP, Luz HR, Flausino W, Ferreira I, Lopes CWG. Isospora piacobrai n. sp. (Apicomplexa: Eimeriidae) from the masked yellowthroat Geothlypis aequinoctialis (Gmelin) (Passeriformes: Parulidae) in South America. Syst Parasitol 2009c; 75 (3): 225-230. PMid:20157796. http://dx.doi. org/10.1007/s11230-009-9221-7

Berto BP, Balthazar LMC, Flausino W, Lopes CWG. Three new species of Isospora Schneider, 1881 (Apicomplexa: Eimeriidae) from the buffy-fronted seedeater Sporophila frontalis Verreaux (Passeriformes: Emberizidae) from South America. Syst Parasitol 2009d; 73(1): 65-69. PMid:19337860. http://dx.doi.org/10.1007/s11230-009-9180-z

Berto BP, Balthazar LMC, Flausino W, Lopes CWG. New isosporoid coccidian parasites of sayaca tanager, Thraupis sayaca, from South America. Acta Parasitol 2009e; 54(2): 90-94. http://dx.doi.org/10.2478/ s11686-009-0014-6

Berto BP, Flausino W, Luz HR, Ferreira I, Lopes CWG. Two new Isospora species from Brazilian tanager (Ramphocelus bresilius dorsalis) of South America. Parasitol Res 2009f; 105(3): 635-639. PMid:19399519. http:// dx.doi.org/10.1007/s00436-009-1432-y

Berto BP, Lopes B, Teixeira-Filho WL, Flausino W, Lopes CWG. Coccídios de invertebrados associados ao hábito alimentar de vertebrados: Uma revisão dos gêneros Adelea, Adelina e Barroussia. Rev Bras Med Vet 2010a; 32(1): 33-41.

Berto BP, Flausino W, Luz HR, Ferreira I, Lopes CWG. Isospora ramphoceli n. sp. (Apicomplexa: Eimeriidae) from the Brazilian tanager (Aves: Passeriformes: Thraupidae) Ramphocelus bresilius dorsalis Sclater, 1855. Zootaxa 2010b; 2650(1): 57-62.

Berto BP, Luz HR, Ferreira I, Flausino W, Lopes CWG. Two new hosts for Isospora tiesangui Berto, Flausino, Luz, Ferreira \& Lopes, 2008 (Apicomplexa: Eimeriidae). Rev Bras Med Vet 2010c; 32(3): 169-171.

Berto BP, Luz HR, Ferreira I, Flausino W, Lopes CWG. A diagnostic tool to identify species of the genus Isospora Schneider, 1881 (Apicomplexa: Eimeriidae) based on sporulated oocyts from Thaupidae family (Aves: Passeriformes): A dichotomous key. Rev Bras Med Vet 2010d; 32(3): 182186.

Berto BP, Flausino W, McIntosh D, Teixeira-Filho WL, Lopes CWG. Coccidia of New World passerine birds (Aves: Passeriformes): a review of Eimeria Schneider, 1875 and Isospora Schneider, 1881 (Apicomplexa: Eimeriidae). Syst Parasitol 2011a; 80 (3): 159-204. PMid:22002022. http://dx.doi.org/10.1007/s11230-011-9317-8

Berto BP, Luz HR, Flausino W, Teixeira-Filho WL, Ferreira I, Lopes CWG. Isosporoid coccidia (Apicomplexa: Eimeriidae) parasites of tanagers (Passeriformes: Thraupidae) from the Marambaia Island, Brazil. Pesq Vet Bras 2011b; 31(9): 798-805. http://dx.doi.org/10.1590/S0100736X2011000900012
Berto BP, Flausino W, Luz HR, Ferreira I, Lopes CWG. Isospora coerebae n. sp. (Apicomplexa: Eimeriidae) from the bananaquit Coereba flaveola (Passeriformes: Coerebidae) in South America. Rev Bras Parasitol Vet 2011c; 20(1): 22-26. PMid:21439227. http://dx.doi.org/10.1590/ S1984-29612011000100005

Berto BP, Ferreira I, Flausino W, Teixeira-Filho WL, Lopes CWG. Isospora canaria Box, 1975 (Apicomplexa: Eimeriidae) from canaries Serinus canaria Linnaeus (Passeriformes: Fringillidae) in Brazil. Syst Parasitol 2013a; 85(1): 49-53. PMid:23595491. http://dx.doi. org/10.1007/s11230-012-9402-7

Berto BP, Borba HR, Lima VM, Flausino W, Teixeira-Filho WL, Lopes CWG. Eimeria spp. from Japanese quails (Coturnix japonica): new characteristic features and diagnostic tools. Pesq Vet Bras 2013b; 33(12): 1441-1447. http://dx.doi.org/10.1590/S0100736X2013001200008

Berto BP, Lopes CWG. Distribution and Dispersion of Coccidia in Wild Passerines of the Americas. In. Ruiz L, Iglesias F. Birds: Evolution and Behavior, Breeding Strategies, Migration and Spread of Disease. New York: Nova Science Publishers. 2013. p. 47-66.

Box ED. Isospora as an extraintestinal parasite of passerine birds. J Protozool 1981; 28(2): 244-246. http://dx.doi. org/10.1111/j.1550-7408.1981.tb02842.x

Cardozo SV, Berto BP, Cardozo TSF, Mesquisa EFM, Lopes CWG. Oocysts of Cryptosporidium Tyzzer, 1907 (Apicomplexa: Cryptosporidiidae) in brown mussels Perna perna L., 1758 (Mollusca: Bivalviae) in Ponta do Tinguí, Mangaratiba, RJ: A biomarker of environmental contamination. Coccidia 2013; 1(2): 32-38.

Carvalho FS, Wenceslau AA, Teixeira M, Matos-Carneiro JA, Melo ADB, Albuquerque GR. Diagnosis of Eimeria species using traditional and molecular methods in field studies. Vet Parasitol 2011; 176(2-3): 95 100. PMid:21167646. http://dx.doi.org/10.1016/j.vetpar.2010.11.015

Casas MC, Duszynski DW, Zalles LM. Three new eimerians in capybara (Hydrochaeris hydrochaeris) populations from Eastern Bolivia and Southern Venezuela. J Parasitol 1995; 81(2): 247-251. PMid:7707202. http://dx.doi.org/10.2307/3283928

Catchpole J, Norton C, Joyner L. The occurrence of Eimeria weybridgensis and other species of coccidia in lambs in England and Wales. Br Vet J 1975; 131(4): 392-401. PMid:1148806.

Chapman HD, Barta JR, Blake D, Gruber A, Jenkins M, Smith $\mathrm{NC}$, et al. A selective review of advances in coccidiosis research. $A d v$ Parasitol2013; 83: 93-171. PMid:23876872. http://dx.doi.org/10.1016/ B978-0-12-407705-8.00002-1

Chinchilla M, Valerio I, Sánchez R, González A, Martínez L, Duszynski DW. Two new Eimeria spp.(Apicomplexa: Eimeriidae) from the dusky rice rat, Melanomys caliginosus, Tome 1860, in Costa Rica. J Parasitol 2013; 99(1): 82-84. PMid:22924929. http://dx.doi. org/10.1645/GE-3144.1

Coelho CD, Berto BP, Neves DM, Oliveira VM, Flausino W, Lopes, CWG. Isospora mimusi n.sp. (Apicomplexa: Eimeriidae) from the tropical mockingbird Mimus gilvus in South America. Acta Protozool 2011a; 50 (2): $137-140$.

Coelho CD, Berto BP, Neves DM, Oliveira VM, Flausino W, Lopes CWG. Two new Isospora species from the saffron finch, Sicalis flaveola in Brazil. Acta Parasitol2011b; 56 (3): 239-244. http://dx.doi.org/10.2478/ s11686-011-0051-9

Coelho CD, Berto BP, Neves DM, Oliveira VMD, Flausino W, Lopes CWG. Oocyst shedding by green-winged-saltator (Saltator similis) in 
the diagnostic of coccidiosis and Isospora similisi n. sp. (Apicomplexa: Eimeriidae). Rev Bras Parasitol Vet 2013; 22(1): 64-70. PMid:24252953. http://dx.doi.org/10.1590/S1984-29612013000100012

Cosendey RIJ, Fiúza VRS, Teixeira CS, Oliveira FCR. Freqüência de oocistos de coccídios do gênero "Cryptosporidium" em ovinos no estado do Rio de Janeiro. Rev Bras Saúde Prod An 2008; 9(4): 687-695.

Daugschies A, Imarom S, Bollwahn W. Differentiation of porcine Eimeria spp. by morphologic algorithms. Vet Parasitol 1999; 81(3): 201-210. http://dx.doi.org/10.1016/S0304-4017(98)00246-5

De Souza PNB, Bomfim TCB, Huber F, Abboud LCS, Gomes RS. Natural infection by Cryptosporidium sp., Giardia sp. and Eimeria leuckarti in three groups of equines with different handlings in Rio de Janeiro, Brazil. Vet Parasitol 2009; 160(3-4): 327-333. PMid:19117684. http://dx.doi.org/10.1016/j.vetpar.2008.10.103

Dolnik OV, Palinauskas V, Bensch S. Individual oocysts of Isospora (Apicomplexa: Coccidia) parasites from avian feces: from photo to sequence. J Parasitol 2009; 95(1): 169-174. PMid:19245285. http:// dx.doi.org/10.1645/GE-1873.1

Dubey JP, Hill DE, Lindsay DS, Jenkins MC, Uggla A, Speer CA. Neospora caninum and Hammondia heydorni are separate species/ organisms. Trends Parasitol 2002; 18(2): 66-69. http://dx.doi. org/10.1016/S1471-4922(01)02172-9

Duszynski D. Increase in size of Eimeria separata oocysts during patency. J Parasitol 1971; 57(5): 948-952. PMid:5133901. http://dx.doi. org/10.2307/3277841

Duszynski DW. Coccidian Parasites (Apicomplexa: Eimeriidae) from Insectivores: New Species from Shrew Moles (Talpidae) in the United States. J Protozool 1985; 32(4): 577-580. PMid:4067874. http://dx.doi. org/10.1111/j.1550-7408.1985.tb03080.x

Duszynski DW, Wilber PG. A guideline for the preparation of species descriptions in the Eimeridae. J Parasitol 1997; 83(2): 333-336. http:// dx.doi.org/10.2307/3284470

Duszynski DW, Couch L, Upton SJ. The coccidia of the world [online]. 1999 [cited 2013 Jul 08]. Available from: http://www.k-state. edu/parasitology/worldcoccidia/index.html.

El-Shahawi GA, El-Fayomi HM, Abdel-Haleem HM. Coccidiosis of domestic rabbit (Oryctolagus cuniculus) in Egypt: light microscopic study. Parasitol Res 2012; 110(1): 251-258. PMid:21647671. http://dx.doi. org/10.1007/s00436-011-2479-0

El-Sherry S, Ogedengbe ME, Hafeez MA, Barta JR. Divergent nuclear $18 \mathrm{~S}$ rDNA paralogs in a turkey coccidium, Eimeria meleagrimitis, complicate molecular systematics and identification. Int J Parasitol 2013; 43(8): 679685. PMid:23639264. http://dx.doi.org/10.1016/j.ijpara.2013.03.005

Ellis JT, Morrison DA, Liddell S, Jenkins MC, Mohammed $\mathrm{OB}$, Ryce C, et al. The genus Hammondia is paraphyletic. Parasitology 1999; 118(4): 357-362. PMid:10340325. http://dx.doi. org/10.1017/S0031182098003801

Entzeroth R, Scholtyseck E, Sezen IY. Fine structural study of Eimeria truncata from the domestic goose (Anser anser dom.). $Z$ Parasitenkd 1981; 66(1): 1-7. PMid:7324535. http://dx.doi.org/10.1007/ BF00941939

Fayer R. Epidemiology of protozooan infection: the Coccidia. Vet Parasitol 1980; 6(1-3): 75-103. http://dx.doi.org/10.1016/03044017(80)90039-4
Flausino G, Berto BP, McIntosh D, Furtado TT, Teixeira-Filho WL, Lopes CWG. Phenotypic and genotypic characterization of Eimeria caviae from guinea pigs. Acta Protozool 2014; 53(3). In press.

Fournie JW, Vogelbein WK, Overstreet RM, Hawkins WE. Life cycle of Calyptospora funduli (Apicomplexa: Calyptosporidae). J Parasitol 2000; 86(3): 501-505. PMid:10864246.

Frenkel JK, Dubey JP. The taxonomic importance of obligate heteroxeny: Distinction of Hammondia hammondi from Toxoplasma gondii-another opinion. Parasitol Res 2000; 86(10): 783-786. http://dx.doi.org/10.1007/ s004360000261

Friedman CS, Gardner GR, Hedrick RP, Stephenson M, Cawthorn RJ, Upton SJ. Pseudoklossia haliotis sp. n. (Apicomplexa) from the Kidney of California abalone Haliotis spp. (Mollusca). J Invertebr Pathol 1995; 66(1): 33-38. http://dx.doi.org/10.1006/jipa.1995.1057

Fritsche TR. Studies on the Coccidian Parasites (Apicomplexa: Eimeriidae and Pfeifferinellidae) of Pulmonate Gastropods. JProtozool 1987; 34(1): 7578. http://dx.doi.org/10.1111/j.1550-7408.1987.tb03135.x

Gardiner CH, Fayer R, Dubey JP. An atlas of protozoan parasites in animal tissues. Washington: American Registry of Pathology; 1998.

Gardner S, Duszynski D. Polymorphism of eimerian oocysts can be a problem in naturally infected hosts: an example from subterranean rodents in Bolivia. J Parasitol 1990; 76(6): 805-811. http://dx.doi. org/10.2307/3282798

Gomez F, Navarrete I, Rodriguez R. Influencia de los factores ambientales sobre diferentes poblaciones de Isospora lacazei Labbé, 1983 (Protozoa: Apicomplexa). Rev Iber Parasitol 1982; 42(2): 185-196.

Grulet O, Landau I, Baccam D. Les Isospora du Moineau domestique; multiplicite des especes. Ann Parasitol Hum Comp 1982; 57(3): 209-233. PMid:7137798.

Hauck R, Hafez HM. Description of Eimeria pavonina (Coccidia) of Peafowl in Germany. Avian Dis 2012; 56(1): 238-242. http://dx.doi. org/10.1637/9864-072711-Case.1

Hassum IC, Valladares GS, De Menezes RDCA. Diferenciação das espécies de Eimeria parasitas de ovinos pelo uso da regressão linear e algoritmos morfológicos. Rev Bras Parasitol Vet 2007; 16(2): 97-104. PMid:17706012.

Hofstatter PG, Kawazoe U. Two New Eimeria Species (Apicomplexa: Eimeriidae) From the Yellow-Crowned Amazon Amazona ochrocephala (Aves: Psittacidae) in Brazil. J Parasitol 2011; 97(3): 503-505. PMid:21506846. http://dx.doi.org/10.1645/GE-2681.1

Jirků M, Modrý D, Slapeta JR, Koudela B, Lukeš J. The phylogeny of Goussia and Choleoeimeria (Apicomplexa; Eimeriorina) and the evolution of excystation structures in coccidia. Protist 2002; 153(4): 379-390. PMid:12627867. http://dx.doi.org/10.1078/14344610260450118

Joyner LP. Host and Site specificity. In: Long PL. The biology of the Coccidia. Baltimore: University Park Press; 1982. p. 35-62.

Kopečná J, Jirkü M, Oborník M, Tokarev YS, Lukeš J, Modrý D. Phylogenetic analysis of coccidian parasites from invertebrates: search for missing links. Protist 2006; 157(2): 173-183. PMid:16621694. http:// dx.doi.org/10.1016/j.protis.2006.02.005

Lainson R, Shaw JJ. Two new species of Eimeria and three new species of Isospora (Apicomplexa: Eimeriidae) from Brazilian mammals and birds. Bull Mus Natl Hist Nat Paris 1989; 11(2): 349-365.

Levine ND. Apicomplexa. In. Parker SP. Synopsis and Classification of Living Organisms. New York: McGraw-Hill; 1982. p. 571-587. 
Levine ND. The genera Barrouxia, Defretinella, and Goussia of the coccidian family Barrouxiidae (Protozoa: Apicomplexa). J Protozool 1983; 30(3): $542-$ 547. http://dx.doi.org/10.1111/j.1550-7408.1983.tb01419.x

Levine ND. Veterinary Protozoology. Ames: Iowa State University Press; 1985.

Lew AE, Anderson GR, Minchin CM, Jeston PJ, Jorgensen WK. Interand intra-strain variation and PCR detection of the internal transcribed spacer 1 (ITS-1) sequences of Australian isolates of Eimeria species from chickens. Vet Parasitol 2003; 112: 33-50. http://dx.doi.org/10.1016/ S0304-4017(02)00393-X

Lin RQ, Qiu LL, Liu GH, Wu XY, Weng YB, Xie WQ, et al. Characterization of the complete mitochondrial genomes of five Eimeria species from domestic chickens. Gene 2011; 480(1-2): 28-33. PMid:21402132. http://dx.doi.org/10.1016/j.gene.2011.03.004

Lopes BB, Berto BP, Luz HR, Galvão GS, Lopes CWG. The ruby-crowned tanager Tachyphonus coronatus Vieillot (Passeriformes: Thraupidae): a new host for Isospora navarroi Berto, Flausino, Luz, Ferreira, Lopes, 2009 (Apicomplexa: Eimeriidae). Coccidia 2013; 1(1): 2-5.

Lopes B, Berto BP, Luz HR, Galvão GS, Ferreira I, Lopes CWG. Isospora massardi sp. nov. (Apicomplexa: Eimeriidae) from the white-necked thrush Turdus albicollis (Passeriformes: Turdidae) from Brazil. Acta Parasitol 2014; 59(2). In press. PMid:24570068.

Mai K, Sharman PA, Walker RA, Katrib M, Souza D, McConville MJ, et al. Oocyst wall formation and composition in coccidian parasites. Mem Inst Oswaldo Cruz 2009; 104(2): 281-289. PMid:19430654. http:// dx.doi.org/10.1590/S0074-02762009000200022

McAllister CT. Pfeifferinella gugleri (Apicomplexa: Pfeifferinellidae) from Roemer's Snail Mesodon roemeri (Gastropoda: Polygyridae) in North Central Texas U.S.A. Comp Parasitol 2013; 80(1): 120-122. http:// dx.doi.org/10.1654/4580.1

McAllister CT, Upton SJ. The coccidia (Apicomplexa: Eimeriidae) of testudines, with descriptions of three new species. Can $J$ Zool 1989; 67(10): 2459-2467. http://dx.doi.org/10.1139/z89-347

McCully RM, Basson PA, De-Vos V, De-Vos AJ. Uterine coccidiosis of the impala caused by Eimeria neitzi spec. nov. Onderstepoort $J$ Vet Res 1970; 37(1): 45-58. PMid:5526338.

McQuistion TE, Capparella A. Isospora ubique: a new coccidian parasite from the wedge-billed woodcreeper (Glyphorynchus spirurus) from South America. Acta Protozool 1997; 36(1): 75-78.

McQuistion TE, Holmes BB. Isospora robini sp. n., a new coccidian parasite (Apicomplexa: Eimeriidae) from the American robin (Turdus migratorius). Proc Helmint Soc Washington 1988; 55(2): 324-325.

Mehlhorn H, Heydorn AO. Neospora caninum: Is it really different from Hammondia heydorni or is it a strain of Toxoplasma gondii? An opinion. Parasitol Res 2000; 86(2): 169-178. http://dx.doi.org/10.1007/ s004360050028

Meireles MV, Figueiredo PC. Isolamento e identificação de Cryptosporidium baileyi Current et al., 1986 (Apicomplexa: Cryptosporidiidae) em frangos de corte. Rev Bras Parasitol Vet 1992; 1(2): 125-130.

Mladineo I, Bočina I. Extraintestinal gamogony of Aggregata octopiana in the reared common octopus (Octopus vulgaris) (Cephalopoda: Octopodidae). J Invertebr Pathol 2007; 96(3): 261-264. PMid:17603071. http://dx.doi.org/10.1016/j.jip.2007.05.010

Modrý D, Slapeta JR, Jirkü M, Oborník M, Lukeš J, Koudela B. Phylogenetic position of a renal coccidium of the European green frogs, 'Isospora' lieberkuehni Labbé, 1894 (Apicomplexa: Sarcocystidae) and its taxonomic implications. Int J Syst Evol Microbiol 2001; 51(3): 767-772. PMid:11411696. http://dx.doi.org/10.1099/00207713-51-3-767

Modrý D, Jirkü M, Šumbera R. Three new species of Eimeria (Apicomplexa: Eimeriidae) from the silvery mole rat Heliophobius argenteocinereus Peters, 1846 (Rodentia: Bathyergidae) from Malawi. J Parasitol 2005; 91(5): 1200-1203. PMid:16419767. http://dx.doi. org/10.1645/GE-3468.1

Modrý D, Jirkü M. Three new species of coccidia (Apicomplexa: Eimeriorina) from the marble-throated skink, Marmorosphax tricolor Bavay, 1869 (Reptilia: Scincidae), endemic to New Caledonia with a taxonomic revision of Eimeria spp. from scincid hosts. Parasitol Res 2006; 99(4): 419-428. PMid:16596416. http://dx.doi.org/10.1007/ s00436-005-0106-7

Mohammed OB, Alagaili AN, Omer SA. Redescription of Eimeria dorcadis Mantovani 1966 (Apicomplexa: Eimeriidae) from the dorcas gazelle (Gazella dorcas) in Saudi Arabia. Folia Parasitol 2012; 59(1): $27-$ 31. PMid:22439425. http://dx.doi.org/10.14411/fp.2012.005

Morrison DA, Bornstein S, Thebo P, Wernery U, Kinne J, Mattsson JG. The current status of the small subunit rRNA phylogeny of the coccidia (Sporozoa). Int J Parasitol 2004; 34(4): 501-514. PMid:15013740. http:// dx.doi.org/10.1016/j.ijpara.2003.11.006

Motriuk-Smith D, Seville RS, Quealy L, Oliver CE. Comparison of the ITS1 and ITS2 rDNA in Eimeria callospermophili (Apicomplexa: Eimeriidae) from Sciurid Rodents. J Parasitol 2011; 97(2): 305-310. PMid:21506777 PMCid:PMC3157313. http://dx.doi.org/10.1645/ GE-2535.1

Norton CC, Joyner LP. Eimeria acervulina and E. mivati: oocysts, life-cycle and ability to develop in the chiken embryo. Parasitology 1981; 83(2): 269279. PMid:7329717. http://dx.doi.org/10.1017/S0031182000085280

Novilla MN, Carpenter JW, Spraker TR, Jeffers TK. Parental Development of Eimerian Coccidia in Sandhill and Whopping Cranes. J Eukaryot Microbiol 1981; 28(2): 248-255.

Nowell F, Higgs S. Eimeria species infecting wood mice (genus Apodemus) and the transfer of two species to Mus musculus. Parasitology 1989; 98(3): 329-336. http://dx.doi.org/10.1017/ S0031182000061394

Ogedengbe JD, Hunter DB, Barta JR. Molecular identification of Eimeria species infecting market-age meat chickens in commercial flocks in Ontario. Vet Parasitol 2011a; 178(3-4): 350-354. PMid:21295915. http://dx.doi.org/10.1016/j.vetpar.2011.01.009

Ogedengbe JD, Hanner RH, Barta JR. DNA barcoding identifies Eimeria species and contributes to the phylogenetics of coccidian parasites (Eimeriorina, Apicomplexa, Alveolata). Int J Parasitol 201 1b; 41(8): 843 850. PMid:21515277. http://dx.doi.org/10.1016/j.ijpara.2011.03.007

Odening K. The present state of species-systematics in Sarcocystis Lankester, 1882 (Protista: Sporozoa: Coccidia). Syst Parasitol 1998; 41(3): 209-233. http://dx.doi. org/10.1023/A:1006090232343

Owen D. Life cycle of Eimeria stiedae. Nature 1970; 227: 304 PMid:5428207. http://dx.doi.org/10.1038/227304a0

Paperna I, Lainson R. Fine structure of the epicytoplasmic eimerid coccidium Acroeimeria pintoi Lainson \& Paperna, 1999, a gut parasite of the lizard Ameiva ameiva in North Brazil. Parasite 1999; 6(4): 359364. PMid:10633508.

Parker B, Duszynski D. Polymorphism of eimerian oocysts: a dilemma posed by working with some naturally infected hosts. $J$ Parasitol 1986; 72(4): 602-604. http://dx.doi.org/10.2307/3281518 
Pereira LQ, Berto BP, Flausino W, Lovato M, Lopes CWG. Isospora bocamontensis n. sp. (Apicomplexa: Eimeriidae) from the yellow cardinal Gubernatrix cristata (Vieillot) (Passeriformes: Emberizidae) in South America. Syst Parasitol 2011; 78(2): 73-80. PMid:21161493. http:// dx.doi.org/10.1007/s11230-010-9278-3

Ramirez L, Teixeira-Filho WL, Flausino W, Berto BP, Almeida CRR, Lopes CWG. Contribuição sobre a morfologia das espécies do gênero Eimeria (Apicomplexa: Eimeriidae) de suínos do Município de Rio Claro, Estado do Rio de Janeiro. Rev Bras Med Vet 2008a; 30(4): 238-242.

Ramirez L, Teixeira-Filho WL, Flausino W, Berto BP, Almeida CRR. Importância das técnicas diagnósticas para oocistos do gênero Cryptosporidium Tyzzer, 1907 (Apicomplexa: Cryptosporidiidae) de suínos do Vale do Paraíba, Sul Fluminense, RJ. Rev Bras Med Vet 2008b; 30(2): 111-114.

Ramirez L, Berto BP, Teixeira-Filho WL, Flausino W, Meireles GS, Rodrigues JS, et al. Eimeria bareillyi from the domestic water buffalo Bubalus bubalis in the State of Rio de Janeiro Brazil. Rev Bras Med Vet 2009a; 31(4): 261-264.

Ramirez L, Teixeira-Filho WL, Berto BP, Balthazar LMC, Lopes CWG. Caracterização de variações morfométricas com a utilização da regressão linear em espécies do gênero Eimeria em caprinos da região serrana do estado do Rio de Janeiro, Brasil. Rev Bras Med Vet 2009b; 31(3): 175-180.

Ratnasingham S, Hebert PD. BOLD: The Barcode of Life Data System (http://www. barcodinglife. org). Mol Ecol Notes 2007; 7(3): 355-364.

Rosales MJ, Mascaro C. First report of Cyclospora talpae (Pellerdy et Tanyi, 1968) (Apicomplexa) in Talpa occidentalis (Insectivora) in the Iberian Peninsula. Res Rev Parasitol 1999; 59(3-4): 135-136.

Samarasinghe B, Johnson J, Ryan U. Phylogenetic analysis of Cystoisospora species at the rRNA ITS1 locus and development of a PCR-RFLP assay. Exp Parasitol 2008; 118(4): 592-595. PMid:18067892. http://dx.doi. org/10.1016/j.exppara.2007.10.015

Sampaio IBM. Estatística aplicada à experimentação animal. Belo Horizonte: FEPMVZ; 2002.

Schwarz RH, Jenkins MC, Klopp S, Miska KB.Genomic analysis of Eimeria spp. populations in relation to performance levels of broiler chicken farms in Arkansas and North Carolina. J Parasitol 2009; 95(4): 871-880. PMid:20049993. http://dx.doi.org/10.1645/GE-1898.1

Scott DT, Duszynski DW. Eimeria from Bats of the World: Two New Species from Myotis spp. (Chiroptera: Vespertilionidae). J Parasitol 1997; 83(3): 495-501. PMid:9194833. http://dx.doi. org/10.2307/3284416

Segade P, Crespo C, Ayres C, Cordero A, Arias MC, García-Estévez JM, et al. Eimeria species from the European pond turtle, Emys orbicularis (Reptilia: Testudines), in Galicia (NW Spain), with description of two new species. J Parasitol 2006; 92(1): 69-72. PMid:16629318. http:// dx.doi.org/10.1645/GE-3491.1

Silva AC, Divino-Lima J. Eimeria minasensis n. sp. (Apicomplexa: Eimeriidae) in the Domestic Goat Capra hircus from Brazil. Mem Inst Oswaldo Cruz 1998; 93(6): 741-744. PMid:9921296. http://dx.doi. org/10.1590/S0074-02761998000600009

Silva EAT, Literák I, Koudela B.Three new species of Isospora Schneider, 1881 (Apicomplexa: Eimeriidae) from the lesser seed-finch, Oryzoborus angolensis (Passeriformes: Emberizidae) from Brazil. Mem Inst Oswaldo Cruz 2006; 101(5): 573-576. http://dx.doi.org/10.1590/ S0074-02762006000500016

Široký P, Modrý D. Two eimerian coccidia (Apicomplexa: Eimeriidae) from the critically endangered arakan forest turtle Heosemys depressa
(Testudines: Geoemydidae) with description of Eimeria arakanensis n. sp. Acta Protozool 2006; 45(2): 183-189.

Široký P, Modrý D. Eimeriid coccidia (Apicomplexa: Eimeriidae) from Geoemydid turtles (Testudines: Geoemydidae) with a description of six new species. Acta Protozool 2010; 49(4): 301-310.

Soulsby EJ. Parasitología y enfermedades parasitarias en los animales domésticos. México: Interamericana; 1987.

Tenter AM, Barta JR, Beveridge I, Duszynski DW, Mehlhorn H, Morrison DA, et al. The conceptual basis for a new classification of the coccidia. Int J Parasitol 2002; 32(5): 595-616. http://dx.doi.org/10.1016/ S0020-7519(02)00021-8

Turner WC, Versfeld WD, Kilian JW, Getz WM. Synergistic effects of seasonal rainfall parasites and demography on fluctuations in springbok body condition. J Anim Ecol 2012 81(1): 58-69. PMid:21831195 PMCid:PMC3217112. http://dx.doi.org/10.1111/ j.1365-2656.2011.01892.x

Upton SJ, Current WL, Clubb SL. Two new species of Isospora (Apicomplexa: Eimeriidae) from passeriform birds of South America. Syst Parasitol 1985; 7(3): 227-229. http://dx.doi.org/10.1007/BF00011453

Upton SJ, Marchiondo AA, Williams RN. New species of Isospora (Apicomplexa: Eimeriidae) from passeriform birds of Hawaii. Syst Parasitol 1988; 12(2): 81-85. http://dx.doi.org/10.1007/BF00000141

Upton SJ, Stamper MA, Whitaker BR. Isospora bellicosa sp. n. (Apicomplexa) from a Peruvian red-breasted meadowlark, Sturnella bellicosa (Passeriformes: Icteridae). Archiv fur Protistenk 1995; 145(12): 132-134.

Upton SJ. Suborder Eimeriorina Léger, 1911. In: Lee JJ, Leedale GF, Bradbury P. An Illustrated Guide to the Protozoa. 2nd ed. London: Society of Protozoologists; 2000. p. 318-339.

Upton SJ, Whitaker BR. New species of Isospora (Apicomplexa, Eimeriidae) from the troupial and white-edged oriole (Icterus spp.) (Aves, Passeriformes, Icteridae). Acta Parasitol 2000; 45: 67-70.

Vrba V, Poplstein M, Pakandl M. The discovery of the two types of small subunit ribosomal RNAgene in Eimeria mitis contests the existence of E. mivati as an independent species. Vet Parasitol 2011; 183(1-2): $47-$ 53. PMid:21767912. http://dx.doi.org/10.1016/j.vetpar.2011.06.020

Wacha RS. On the Taxonomic Status of the Family Pfeifferinellidae (Coccidia), with a Description of Pfeifferinella gugleri sp. n. J Protozool 1980; 27(4): 368-371. http://dx.doi. org/10.1111/j.1550-7408.1980.tb05378.x

Wenyon CM. Protozoology. New York: William, Wood and Company. 1926.

Whipps CM, Fournie JW, Morrison DA, Azevedo C, Matos E, Thebo P, et al. Phylogeny of fish-infecting Calyptospora species (Apicomplexa: Eimeriorina). Parasitol Res 2012; 111(3): 1331-1342. PMid:22645034. http://dx.doi.org/10.1007/s00436-012-2969-8

Wünschmann A, Wellehan-Junior JF, Armien A, Bemrick WJ, Barnes D, Averbeck GA, et al. Renal infection by a new coccidian genus in big brown bats (Eptesicus fuscus). J Parasitol 2010; 96(1): 178-183. PMid:19863159. http://dx.doi.org/10.1645/GE-2250.1 